\title{
STRATEGI PEMBELAJARAN NILAI-NILAI AGAMA DI RAUDHATUL ATFAL ASSU`ADA CIJERAH BANDUNG
}

\author{
Sri Watini \\ STKIP Panca Sakti Bekasi \\ srie.watini@gmail.com
}

\begin{abstract}
Abstrak
Penelitian ini bertujuan untuk mendeskripsikan Strategi Pembelajaran Nilai-nilai Agama di Raudhatul Athfal Assu`ada dengan alamat Jl. Cijerah Komplek Pesantren No. 83 Telp.(022) 6075882 ,email: madrasahassuada@gmail.com. Adapun metode penelitian yang digunakan adalah deskriptif kualitatif dalam rangka menggambarkan secara komprehensif dari data-data atau informasi yang diperoleh selama penelitian dengan penyajian apa adanya sesuai dengan keadaan yang sesungguhnya. Data atau informasi yang didapatkan didokumentasikan sebagai bukti otentik hasil penelitian berupa CW (Catatan Wawancara), CD (Catatan Dokumentasi), CO (Catatan Observasi) dan CL (Catatan Lapangan). Dalam penelitian ini populasi yang diambil adalah anak usia dini 5-6 tahun pada lembaga Raudhatul Athfal Assu`ada Jl. Cijerah Komplek Pesantren No. 83 Telp. 022(6075882) email: madrasahassuada@gmail.com, dengan jumlah peserta didik sebanyak 73 anak. Hasil penelitian yang diperoleh berupa gambaran secara umum dan khusus berkaitan dengan aplikasi strategi pembelajaran nilai-nilai agama di RA Assu ada mulai dari berupa komponen SDM, Peserta Didik, Sarana dan Prasarana (fasilitas lembaga), Program Tahunan, Program Semester, Kurikulum, Contoh silabus dan RKH yang digunakan, proses belajar mengajar media yang ada sampai pada kegiatan penilaian.
\end{abstract}

Kata Kunci : Strategi Pembelajaran, Agama, Raudhatul Athfal 


\section{A. Pendahuluan}

Hakikat pendidikan merupakan usaha sadar dan terencana oleh seorang pendidik baik guru, orang tua, maupun orang dewasa yang bertanggung jawab yang mampu menjadikan anakanak memiliki kemandirian, pengetahuan keterampilan, keahlian, dapat memecahkan berbagai masalah yang dihadapi dalam kehidupannya dan berguna bagi dirinya sendiri, keluarga, bangsa maupun negaranya. Hal ini diperkuat dengan dalil Al Qur`an Surat An-Nahl. 78 yang berbunyi:

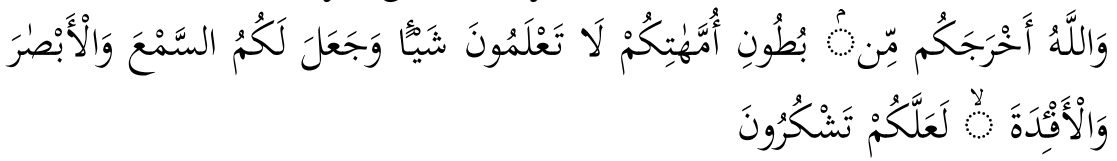

Artinya : Dan Allah mengeluarkan kamu dari perut ibumu dalam keadaan tidak mengetahui sesuatupun, dan Dia memberi kamu pendengaran, penglihatan dan hati, agar kamu bersyukur", [Q.S an-Nahl (16) : 78]

Hakikat pendidikan di sini bukan saja mengajarkan ilmu pengetahuan berkaitan dengan hal-hal yang sifatnya akademik scolastik dalam rangka menjadikan insan yang cerdas tentang halhal ilmu dunia akan tetapi juga mendidik, membimbing, dan mengarahkan bagaimana anak nantinya memiliki kehidupan yang cerdas akan hakikat dirinya sebagai mahkluk yang diciptakan Alloh, Swt untuk beribadah pada-Nya. Kecerdasan akan dirinya dalam menjalankan kehidupannya menjadikan dirinya menjadi manusia yang berintelektual, berakhlak dan beriman. Hal ini tidak terlepas dari hakikat manusia sebagai khalifah di bumi yang harus bertanggungjwawab terhadap apa yang dilakukan serta imbas dari tindakannya.

Pendidikan pada anak usia dini merupakan pendidikan yang paling dasar dalam meletakkan kerangka, landasan atau pondasi kehidupan seorang manusia. Pondasi yang kokoh inilah yang mampu menjadikan anak-anak nantinya memiliki bekal hidup yang kuat sehingga kehidupannya menjadi lebih bermakna. Oleh sebab itu di dalam memberikan pendidikan pada anak harus benar sehingga nantinya menghasilkan pemimpin-pemimpin bangsa yang berkwalitas dari segi kompetensi keahlian dirinya dalam bekerja serta kompetensi akhlaknya sebagai pondasi hidup yang dijalankannya. 
Apalagi anak usia dini mengalami masa golden ages di mana otak berkembang sangat pesat apabila diberikan stimulasi yang tepat, efektif dan efisien dari lingkungannya berupa kegiatan pendidikan dan pembelajaran sesuai dengan tahapan usia, karakteristik, kebutuhan dan minatnya. Inilah gambaran bentuk pendidikan yang seharusnya dilakukan pada anak didik kita. Pertanyaannya apakah proses pendidikan pada anak usia dini kita sudah seperti yang seharusnya. Jawabnya adalah belum, bahkan pendidikan yang ada masih mentitik beratkan pada pemberikan bekal-bekal akademik semata. Pada akhirnya proses pendidikan masih menghasilkan generasi-generasi yang rapuh. Realita membuktikan bahwa pada saat ini banyak sekali tawuran antar siswa maupun mahasiswa, hubungan bebas, aborsi maupun narkoba.

Keadaan ini merupakan akumulasi dari berbagai ketidaktepatan aplikasi pendidikan yang tidak dapat mengena atau menyentuh dari aspek afektif yang lebih mendekatkan pada kecerdasan agama yang seharusnya menjadi esensi dari segala bentuk aplikasi pembelajaran. Imbas yang paling ironis adalah kehidupan masa dewasa yang harus matang dalam sikap, perbuatan dan keterampilan hidup ternyata justru memunculkan banyak koruptor, keculasan, kebohongan, pembunuhan dan halhal yang jauh dari kehidupan sebagai makhluk yang cerdas dari nilai-nilai agama.

Oleh sebab itu maka dalam rangka pelayanan pendidikan bagi anak usia dini perlu betul-betul diperhatikan. Memilih lembaga pendidikan yang tepat bagi para orang tua (stakeholder) menjadi target bagaimana mempersiapkan kehidupan anak-anak didik kita di masa depan.

Lembaga Raudhatul Athfal merupakan salah satu lembaga pendidikan bagi anak-anak usia dini di bawah kementrian agama bisa dipandang sebagai salah satu lembaga pendidikan yang lebih menekankan pada aspek nilai-nilai agama dibandingkan dengan pendidikan anak usia dini seperti Taman Kanak-kanak. Benarkah pernyataan tersebut, hal ini masih perlu dikaji dan diperhatikan lebih mendalam. Karena kenyataan yang ada masih banyak masyarakat maupun lembaga pemerintah yang memandang tataran pendidikan Raudhatul Atfal merupakan pendidikan yang belum begitu penting untuk dilakukan, bahkan memandang remeh dengan sebelah mata. 
Hal ini dapat dilihat dari berbagai contoh seperti, kebijakan pemerintah belum mendukung secara optimal terselenggaranya lembaga raudhatul athfal dilihat dari masih minimnya bantuan media pembelajaran di RA, kurang optimalisasi pengadaan seminar-seminar, workshop untuk pengembangan kompetensi guru-guru RA, sarana dan prasarana yang belum lengkap dan masih sangat minim, bahkan sangat sederhana, kwalitas penyelenggaraan program pembelajaran yang masih rendah dan sebagainya.

Oleh sebab alasan itulah maka menjadi daya tarik peneliti untuk mengamati lembaga Raudhatul Athfal secara lebih dekat. Dengan harapan agar peneliti mendapatkan informasi bagaimana penyelenggaraan Raudhatul Athfal sebagai salah satu pendidikan yang menekankan pada aspek pengembangan nilai-nilai agama pada anak didik.

\section{B. Identifikasi Masalah}

Berdasarkan pada latar belakang maka pokok permasalahannya dapat diindentifikasikan sebagai berikut:

1. Sebagian besar Raudhatul Athfal yang ada di Indonesia belum memiliki fasilitas yang mendukung proses pembelajaran.

2. Guru-guru yang ada belum memiliki kualifikasi sebagai pendidik RA yaitu S1 PGRA/S1 PAUD/S1 Psikologi sesuai ketentuan Undang-undang guru No.14 Tahun 2005.

3. Sebagian besar Raudhatul Athfal belum memiliki media pendukung pembelajaran sesuai dengan kebutuhan.

4. Guru-guru yang ada belum menempatkan ruh nilai-nilai agama dalam aplikasi pembelajaran atau belum mengintegrasikan nilai-nilai agama dengan aspek pengembangan yang lain.

5. Guru-guru Raudhatul Athfal mendapatkan honor mengajar atau gaji yang sangat rendah sehingga kinerjanya kurang bagus.

6. Guru-guru Raudhatul Athfal yang ada belum memiliki kompetensi mengajar yang diharapkan sesuai dengan ketentuan profesi keguruan. 


\section{Rumusan Masalah}

Berdasarkan pada latar belakang masalah maka penelitian ini dirumusakan pada, "Strategi Pembelajaran Nilai-nilai Agama pada Raudhatul Atfal Assu ada Cijerah Bandung".

\section{Pertanyaan Penelitian}

Berdasarkan pada latar belakang masalah, identifikasi dan pembatasan masalah maka dapat dirumuskan pokok permasalahannya dalam hal ini adalah, "Bagaimana Strategi Pembelajaran Nilai-nilai Agama di Raudhatul Athfal Assu`ada Cijerah Bandung".

\section{E. Tujuan Penelitian}

Dalam Penelitian ini memiliki dua ujuan yaitu tujuan Teoriris dan tujuan Praktis. Adapun tujuan teoritisnya adalah "Mengetahui dan mendiskripsikan strategi pembelajaran nilainilai agama pada Raudhatul Athfal Assu ada Cijerah Bandung. Adapun tujuan praktisnya adalah

a. Agar guru-guru Raudhatul Athfal dapat mengembangankan dan meningkatkan kwalitas profesinya.

b. Agar guru-guru Raudhatul Athfal dapat meningkatkan kualitas dalam strategi pengembangan nilai-nilai agama di lembaga masing-masing .

\section{F. Manfaat Penelitian}

1. Hasil penelitian dapat dijadikan sebagai landasan dasar bagi penelitian selanjutnya.

2. Hasil penelitian dapat dijadikan sebagai gambaran bagi para guru Raudhatul Athfal dalam pembelajaran strategi pembelajaran nilai-nilai agama pada lembaga masingmasing.

\section{G. Kajian Pustaka Dan Konsep Teoritis}

a. Strategi Pembelajaran

Hakikat strategi pembelajaran secara bahasa, strategi bisa diartikan sebagai "siasat, kiat, trik, atau cara". Sedang secara umum strategi ialah suatu garis besar haluan dalam bertindak untuk mencapai tujuan yang telah ditentukan. Dalam dunia pendidikan, strategi diartikan sebagai a plan,method, or series of activities designed to achieves a particular educational goal (J.R. David, 1976). 
Dengan demikian strategi pembelajaran dapat diartikan sebagai perencanaan yang berisi tentang rangkaian kegiatan yang didesain untuk mencapai tujuan pndidikan tertentu. Ada dua hal yang dapat dicermati dari pengertian di atas pertama, strategi pembelajaran merupakan rencana tindakan (rangkaian kegiatan) termasuk penggunaan metode dan pemanfaaatan berbagai sumber daya/kekuatan dalam pembelajaran. Ini berarti penyusunan suatu strategi baru sampai pada proses penyusunan rencana kerja belum sampai pada tindakan. Kedua, strategi disusun untuk mencapai tujuan tertentu. Artinya, arah dari semua keputusan penyusunan strategi adalah pencapaian tujuan.

Adapun hakikat pembelajaran sendiri sebenarnya memiliki definisi atau arti. Beberapa definisi pembelajaran dirumuskan antara lain, 1). Duffy dan Roehler (1989) dalam Dimyati (2006) menyatakan, "Pembelajaran adalah suatu usaha yang sengaja melibatkan dan menggunakan pengetahuan profesional yang dimiliki guru untuk mencapai tujuan kurikulum. Menurut Gagne dan Briggs (1979:3) dalam Hamzah B.Uno (2007) mengartikan instruction atau pembelajaran ini adalah suatu sistem yang bertujuan untuk membantu proses belajar siswa, yang berisi serangkaian peristiwa yang dirancang, disusun sedemikian rupa untuk mempengaruhi dan mendukung terjadinya proses belajar siswa yang bersifat internal. Menurut UndangUndang No. 23 Tahun 2003 Tentang SISDIKNAS Pembelajaran adalah proses interaksi peserta didik dengan pendidik dan sumber belajar pada suatu lingkungan belajar.

Menurut Winkel (1991) dalam Abdulrahman (2009) Pembelajaran adalah separangkat tindakan yang dirancang untuk mendukung proses belajar siswa, dengan memperhitungkan kejadia-kejadian ekstrim yang berperan terhadap rangkaian kejadian-kejadian intern yang berlangsung dialami siswa. Dari beberapa peryataan di atas maka dapat disimpulkan bahwa pembelajaran adalah suatu proses kegiatan rekayasa yang dilakukan oleh seorang guru dalam melakukan proses belajar mengajar dimulai dari mendesain kegiatan, proses belajar siswa, sampai pada kegiatan evaluasi sehingga mengasilkan hasil belajar siswa yang optimal.

Hakikat strategi pembelajaran secara komprehensif dirumuskan oleh beberapa para ahli sebagai berikut, 1). Kemp (1995) menjelaskan bahwa strategi pembelajaran adalah suatu kegiatan pembelajaran yang harus dikerjakan guru dan siswa agar tujuan pembelajaran dapat dicapai secara efektif dan efisien, 3). 
Dick and Carey (1985) menyebutkan bahwa strategi pembelajaran itu adalah suatu set materi dan prosedur pembelajaran yang digunakan secara bersama-sama untuk menimbulkan hasil belajar pada siswa, 3). Alwi Suparman (1999) menjelaskan bahwa strategi pembelajaran merupakan perpaduan dari urutan kegiatan dan cara pengorganisasian materi pelajaran, peserta didik, peralatan, bahan serta waktu yang digunakan dalam proses pembelajaran untuk mencapai tujuan yang telah ditetapkan.

Dari beberapa pendapat di atas dapat dirumuskan bahwa strategi pembelajaran adalah prosedur atau langkah-langkah kerja dan direkayasa serta dipilih oleh pendidik dalam mengelola kelas dan diatur secara sistematis dari mulai pemilihan, penetapan komponen tujuan, materi pembelajaran, media, metode, peserta didik, waktu, alat, bahan yang telah ditetapkan.

\section{b. Nilai-nilai Agama}

Menurut Bunyamin (2009) mengatakan nilai adalah apa yang dianggap penting atau berharga bagi individu atau kelompok. Menurut Lawang dalam Bunjamin (2009) nilai adalah gambaran mengenai apa yang diinginkan, yang pantas, yang berharga, yang mempengaruhi perilaku sosial dari orang yang memiliki nilai. Menurut Nordin (2005) Anderson dan Taylor mengemukakan tentang Nilai adalah "Values are the abstract standart in a society or group that define ideal principles." Artinya bahwa nilai merupakan sesuatu yang abstrak dalam masyarakat atau kumpulan dan dianggap sebagai suatu prinsip. Walaupun nilai bersifat abstrak akan tetapi mampu menentukan manusia dalam bertingkah laku pada suatu kelompok masyarakat. nilai inilah yang akan menjadi landasan dalam manusia bertingkah laku.

Melihat pernyataan tersebut maka nilai dapat diartikan sebagai sesuatu yang berguna, dibutuhkan, dianggap baik dan harus ada dalam kehidupan suatu lingkungan sosial masyarakat. Tanpa adanya nilai dalam suatu masyarakat yang dianut maka akan terjadi carut marut kehidupan di lingkungan tersebut. Maka sangatlah penting artinya nilai dalam berkehidupan.

\section{c. Agama}

Agama pada hakekatnya adalah suatu keyakinan akan adanya Tuhan sebagai Sang Pencipta yang tidak bisa dipisahkan dari kehidupan manusia. Dalam uraian tersebut dapat diambil maknanya bahwa adanya hubungan antara manusia dengan agama. Agama dalam islam berarti din mengandung arti 
menguasai, menundukkan, kepatuhan, balasan atau kebiasaan. Din juga dapat diartikan sebagai peraturan-peraturan berupa hukum-hukum yang harus dipatuhi baik dalam bentuk perintah yang wajib dilaksanakan maupun berupa larangan yang harus harus ditinggalkan. Kata din dalam Al Qur'an disebut sebanyak 94 kali dalam berbagai makna dan kontek, antara lain, 1). Agama sebagai pembalasan (Q.S Al Fatihah (1) ayat 4), 2). Agama sebagai Undang-undang duniawi atau peraturan yang dibuat oleh raja (Q.S Yusuf (12)ayat 76), 3). Agama yang datang dari Allah SWT, bila dirangkaikan dengan kata Allah (Q.SAli Imran (3) ayat 83). Menurut Zainuddin (2007) Agama yang dibawa oleh Rasulullah Muhammad SAW sebagai agama yang benar, yakni Islam, bila kata din dirangkaikan dengan kata al-haq (Q.S AtTaubah (9) ayat 33, 5).

Agama selain Islam (Q.S Al Kafirun (109) ayat 6 dan Q.S Ash Shaf (61) ayat 9). Menurut Abu Ahmadi dalam Syafaat (2006) agama menurut bahasa adalah agama berasal dari bahasa Sangsekerta yang diartikan dengan haluan, peraturan, jalan atau kebaktian kepada Tuhan, Agama itu terdiri dari dua perkataan yaitu "A" yang berarti tidak, "Gama" berarti kacau balau, tidak teratur. Jadi agama berarti tidak kacau balau yang berarti teratur.

Kesimpulannya bahwa Agama Islam merupakan suatu undang-undang atau peraturan-peraturan yang mengikat dan mengatur manusia dalam hubungannya dengan Tuhannya dan hubungan manusia dengan sesama manusia dan hubungan manusia dengan alam yang bersumber pada Al Qur'an dan Hadist. Maka orang yang beragama adalah orang yang teratur, orang yang tenteram dan orang yang damai baik dengan dirinya maupun dengan orang lain dari segala aspek kehidupannya.

\section{d. Pendidikan Anak Raudhatul Athfal}

Hakikat Raudhatul Atfal adalah Lembaga Pendidikan bagi anak yang memiliki usia 4-6 tahun di mana usia ini sama atau sederajat dengan anak usia Taman Kanak-kanak. Ketetapan mengenai anak definisi RA tertera dalam Undang-undang SISDIKNAS No. 20 Tahun 2003 pasal 28 ayat 3: Pendidikan anak usia dini pada jalur pendidikan formal berbentuk Taman Kanak-kanak (TK), Raudatul Athfal (RA), atau bentuk lain yang sederajat.

Menurut PP No 17 tahun 2003, (1) Raudhatul Athfal, yang selanjutnya disingkat RA, adalah salah satu bentuk satuan pendidikan anak usia dini pada jalur pendidikan formal yang menyelenggarakan program pendidikan dengan kekhasan agama 
Islam bagi anak berusia 4 (empat) tahun sampai dengan 6 (enam) tahun, (2) RA setara dengan Taman Kanak-Kanak (TK), di mana kurikulumnya ditekankan pada pemberian rangsangan pendidikan untuk membantu pertumbuhan dan perkembangan jasmani dan rohani agar anak memiliki kesiapan dalam memasuki pendidikan lebih lanjut. Wikipedia (2005), Raudatul Athfal (disingkat RA) merupakan jenjang pendidikan anak usia dini (yakni usia 6 tahun atau di bawahnya) dalam bentuk pendidikan formal, di bawah pengelolaan Kementerian Agama.

PP 58 (2009) Penyelenggaraan PAUD jalur pendidikan formal berbentuk Taman Kanak-Kanak (TK)/Raudhatul Atfal (RA) dan bentuk lain yang sederajat, yang menggunakan program untuk anak usia $4-\leq 6$ tahun. Tahap usia $4-\leq 6$ tahun, terdiri dari kelompok usia A : $4-<5$ tahun, kelompok usia B: $5-\leq 6$ tahun. Berdasarkan pada penjabaran tentang Raudahatul Atfal (RA) di atas maka dapat disimpulkan bahwa RA merupakan salah satu lembaga pendidikan anak usia dini 4-6 tahun di bawah naungan Kementrian Agama yang berada di jalur pendidikan formal.

\section{e. Anak Raudhatul Athfal}

Anak Raudhatul Athfal yang memiliki kisaran usia 4-6 tahun memiliki karakateristik yang berbeda dengan orang dewasa. Pada usia ini anak mengalamani masa golden ages atau masa keemasan di mana perkembangan sel-sel syaraf otak mengalami peningkatan yang sangat pesat sekitar apabila mendapatkan stimulasi dari lingkunganya. Perkembangan ini tidak terjadi pada masa lain selain pada masa usia ini. Selain itu semua semua aspek perkembangan seperti kognitif, bahasa, sosial, emosi, kemandirian, jasmani, moral, agama dan berbagai perkembangan lainnya muncul pada masa usia ini.

Karakteristik anak usia dini dikemukakan oleh Sofia Hartati (2005: 8-9) sebagai berikut: 1). memiliki rasa ingin tahu yang besar, 2). merupakan pribadi yang unik, 3). suka berfantasi dan berimajinasi, 4). masa potensial untuk belajar, 5). memiliki sikap egosentris, 6). memiliki rentan daya konsentrasi yang pendek, 7). merupakan bagian dari mahluk sosial. Sementara itu, Rusdinal (2005: 16) menambahkan bahwa karakteristik anak usia 5-7 tahun adalah sebagai berikut: 1) anak pada masa praoperasional, belajar melalui pengalaman konkret dan dengan orientasi dan tujuan sesaat, 2) anak suka menyebutkan namanama benda yang ada disekitarnya dan mendefinisikan kata, 3) anak belajar melalui bahasa lisan dan pada masa ini berkembang 
pesat, 4) anak memerlukan struktur kegiatan yang lebih jelas dan spesifik. Anak-anak hasil pendidikan lembaga Raudhatul Athfal mengaplikasikan nilai-nilai agama dalam kehidupan sehari-hari, sehingga hasil pendidikan agama mampu menjadikan pendidikan yang bermakna dalam kehidupan anak.

\section{f. Metodologi Penelitian}

Dalam penelitian ini peneliti menggunakan metode pendekatan Deskriptif Kualitatif. Menurut Arikunto (2006) pengertian deskriptif adalah suatu jenis penelitian yang berusaha menggambarkan dan menginterpretasi objek sesuai dengan apa adanya. Tujuan utama penelitian deskriptif adalah untuk menggambarkan secara sistematis fakta, karakteristik objek dan subjek yang diteliti secara tepat. Pengertian pendekatan penelitian kwalitatif menurut McMillan \& Schumacher dalam Arikunto adalah suatu pendekatan yang juga disebut pendekatan investigasi karena biasanya peneliti mengumpulkan data dengan cara bertatap muka langsung dan berinteraksi dengan orang-orang di tempat penelitian, Strauss \& Corbin dalam Lezy Moleong (2006), "Penelitian kualitatif juga bisa dimaksudkan sebagai jenis penelitian yang temuan-temuannya tidak diperoleh melalui prosedur statistik atau bentuk hitungan lainnya.

\section{g. Hasil Penelitian dan Pembahasan}

Deskripsi Umum RA Assu’ada

\section{Sejarah RA Assu`ada}

Sejarah Raudhatul Athfal Assu'ada dimulai dari berdirinya yayasan Assu ada pada tahun 1981 oleh Bp. Tholkhah Sholihin dan Ibu Dedeh Cantika. Yayasan Assu ada ini berada di kawaran padat penduduk Kelurahan Cijerah dengan alamat, Jl. Cijerah Komplek Pesantren, Kecamatan Bandung Kulon No. 83 Bandung. Pertama kali berdiri belum memiliki RA akan tetapi baru Madrasah Ibtidaiyah, Madrasah Tsanawiyah dan Pesantren Assu ada. Setiap tahun yayasan ini mengalami perkembangan yang sangat pesat berkaitan dengan jumlah siswa yang ada masuk di Yayasan Assu`ada.

Yayasan Assu ada berdiri di atas lahan kurang lebih 300 meter persegi yang terbagi menjadi beberapa bagian antara lain masjid, dan sekolah. Berdirinya madrasah ini tidak langsung jadi tetapi secara bertahap dari dua kelas, dua kelas dan sekarang sudah ada 6 kelas. Dengan meningkatnya kepercayaan stakeholder yang semakin pesat dilihat dari bertambahnya jumlah peserta didik dari tahun ke tahun maka 
proses pembelajaran berlangsung secara paralel. Untuk kelas pagi jam 08.00-12.00 WIB untuk kelas Madrasah Ibtidaiyah (MI) adapun untuk jam 12.00 - 17.00 WIB untuk kelas Madrasah Tsanawiyah (MTS).

Karena perkembangan dunia anak usia dini semakin gencar maka yayasan inipun mengembangkan sayapnya, tidak hanya MI dan MTS tetapi mendirikan lembaga Pendidikan Anak Usia Dini (PAUD) dalam hal ini Raudhatul Athfal usia 4-5 tahun untuk RA Kelompok A dan usia 5-6 tahun untuk RA Kelompok B. Selain itu ada juga kelompok bermain dengan usia 3-4 tahun. Karena di bawah naungan Kementrian Agama maka penamaan dari lembaganya pun RA berbeda dengan lembaga PAUD pada usia yang sama di bawah Kementrian Pendidikan namanya Taman Kanakkanak (TK). Adapun RA Assu ada berdiri pada tahun 2010. Pada saat ini jumlah peserta didik RA sebanyak 73 anak pada tahun ajaran 2012-2013. Selama berdirinya sampai sekarang sudah dua kali kepemimpinan. Pimpinan pertama oleh KH. Tholhah Sholihin Bisri, Pemimpin kedua H. Arif Ramdani, LC Tahun 1997 sampai sekarang. (CW.1)

2. Visi, Misi dan Tujuan Madrasah Assu`ada

a) Visi

Menjalankan madrasah yang berprestasi dan berkwalitas dengan dasar iman dan taqwa. (CD.1)

b) Misi Madrasah Assu ada

1. Melaksanakan pembelajaran dan hubungan secara efektif sehingga berkembang secara optimal dengan potensinya.

2. Menumbuhkembangkan semangat keunggulan secara intensif kepada seluruh warga sekolah

3. Mendorong dan membantu setiap siswa untuk mengenali potensi dirinya, sehingga dapat berkembang dengan baik

4. Menumbuhkembangkan penghayatan terhadap agama dan budaya bangsa sehingga menjadi sumber kearifan dalam bertindak

5. Melaksanakan ibadah secara secara intensif dan benar (CD.2)

c) Tujuan Madrasah Assu`ada

1. Menyiapkan anak didiik yang siap menjadi anggota masyarakat yang muttaqin. 
2. Mengembangkan potensi siswa untuk memiliki kemampuan dan kompetensi yang unggul. (CD.3)

\section{d) Denah Lokasi RA Assu`ada}

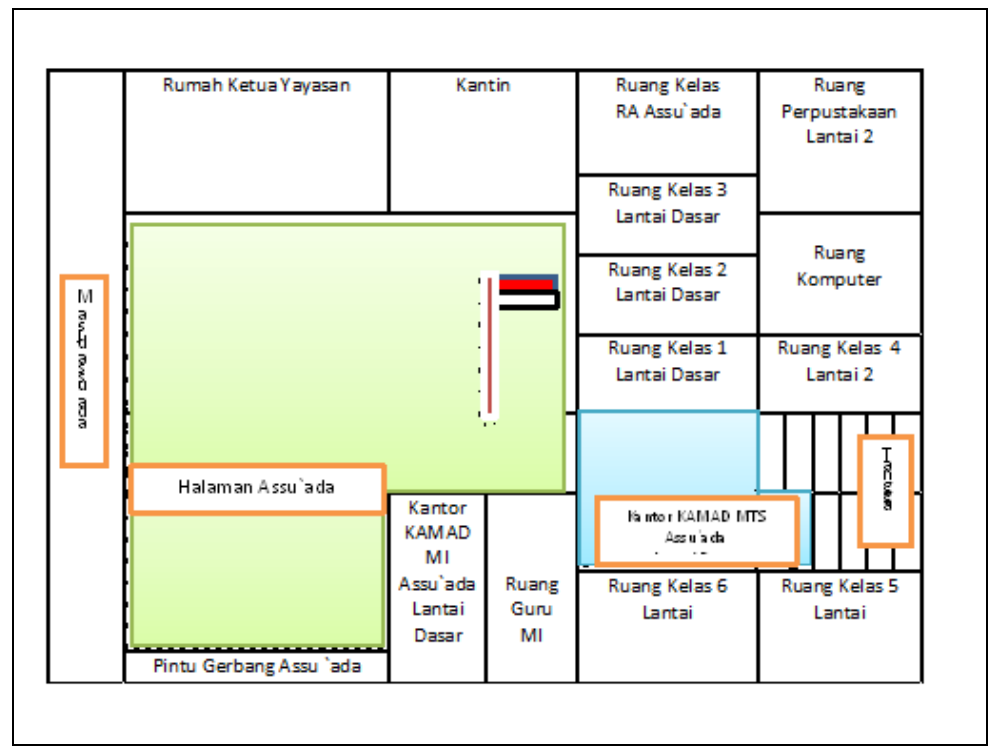

(CD. 4)

\section{h. Deskripsi Khusus dan Pembahasan}

Dalam deskripsi khusus ini mengungkapkan gambaran secara khusus tentang aplikasi Strategi Pembelajaran Nilai-nilai Agama pada Raudhatul Athfal Assu ada beserta komponenkomponennya antara lain: Sumber Daya Manusia dalam hal ini kepala sekolah, guru dan tenaga administrasi, peserta didik, kurikulum (tujuan, kompetensi dasar materi), Silabus atau Satuan Kegiatan Mingguan (SKM), Rencana Kegiatan Harian (RKH), Sarana dan Prasarana, KBM, Kegiatan Penilaian atau Evaluasi. Adapun hasil temuannya sebagai berikut: 


\section{i. SDM (Sumber Daya Manusia)}

Jumlah SDM yang ada di RA Assu`ada:।

\begin{tabular}{|c||l|l|l|}
\hline No & Nama & Jabatan & Pendidikan \\
\hline 1. & Euis Amin NH & Kepala Sekolah & S1 PAI \\
\hline 2. & Lilis Meiliawati & Guru KB & SMA \\
\hline 3. & Irma Imamah & Guru Kelompok A & SMA \\
\hline 4. & Eli Halimah & Guru Kelompok B & SMA \\
\hline \hline
\end{tabular}

(CL. 2)

\section{Pembahasan:}

\section{Sumber Daya Manusia}

Sesuai dengan undang-undang guru no.14 tahun 2005 yang mewajibkan guru PAUD untuk TK/RA adalah S1 PAUD/PGRA. Tujuannya adalah agar guru memiliki kompetensi yang ditetapkan dalam UU seperti pedagogis, professional, kepribadian dan sosial. Oleh sebab itu guru perlu melanjutkan kuliah agar memiliki kompetensi yang ditetapkan sehingga akan memiliki imbas pada hasil pendidikan anak RA berkaitan dengan nilai-nilai agama.

\section{Kurikulum Raudhatul Athfal Assu`ada}

Kurikulum yang dipakai oleh Raudhatul Athfal Assu`ada adalah Kurikulum KBK 2004 untuk TK/RA. (CW.2)

\section{Pembahasan:}

Kurikulum sebagai seperangkat acuan, landasan, pedoman, kerangka dasar yang wajib dan harus dimiliki oleh setiap lembaga pendidikan baik formal, non formal maupun informal. Dalam aplikasinya setiap lembaga harus memiliki kurikulum sesuai dengan aturan yang ada dalam hal ini UU SISDIKNAS No.20 tahun 2003. RA Assu`ada sebagai lembaga pendidikan dibawah naungan Kementrian Agama selain harus memiliki kurikulum yang ditetapkan oleh Kementrian Agama juga sebaiknya memiliki kurikulum dari diknas baik mengacu pada PP 58 tahun 2009 maupun kurikulum 2013 PAUD. Akan tetapi dalam aplikasinya RA Assu adah harus lebih menekankan pada penelrapan kurikulum RA dari kemenag karena di dalam kurikulum RA tentunya memiliki esensi-esensi nilai-nilai agama yang lebih banyak dalam mengembangkan nilai-nilai agama untuk peserta didik. Akan tetapi saat ini kurikulum 2013 pun telah mengedepankan nilai spiritual keagaamaan. 


\section{Silabus atau Satuan Kegiatan Mingguan (SKM), Rencana Kegiatan Mingguan}

Silabus atau Satuan Kegiatan Mingguan yang dipakai oleh Raudhatul Athfal Assu`ada masih mengikuti SKM nya Diknas. (CW.3)

\section{Pembahasan:}

Silabus/Satuan Kegiatan Mingguan(SKM)/ Rencana Kegiatan Mingguan di RA Assu’ada sebaiknya dilengkapi agar dapat mendukung strategi pembelajaran nilai-nilai agama pada anak. RKM yang dibuat dan diperkaya serta mengacu pada format SKM dari Kementrian Agama yang memang memiliki esensi spesifik dalam mengembangkan nilai-nilai agama pada anak, kewirausahaan dan pengembangan karakter dan kepribadian di setiap rencana kegiatannya.

\section{Rencana Kegiatan Harian}

Rencana Kegiatan Harian yang dipakai oleh Raudhatul Athfal Assu ada masih berpedoman pada SKH nya Diknas dalam aplikasi strategi pembelajaran. (CW.4)

\section{Pembahasan:}

Rencana Kegiatan Harian merupakan turunan dari silabus atau RKM. RA Assu ada sebaiknya menggunakan pedoman dari KEMENAG yang menjadi penekan pada nilai-nilai agamanya sudah jelas.

\section{Sarana dan Prasarana RA Assu`ada}

\begin{tabular}{|l||l||l||}
\hline No. & $\begin{array}{l}\text { Nama Sarana dan } \\
\text { Prasarana }\end{array}$ & Keterangan \\
\hline \hline 1. & Ruang Kelas & $\begin{array}{l}1 \text { kelas } \\
\text { Ukuran 3 x 6 meter persegi }\end{array}$ \\
\hline 2. & Meja Guru & 1 buah \\
\hline 3. & Kursi Guru & 3 buah \\
\hline \hline 4. & $\begin{array}{l}\text { Kantor Kepala RA } \\
\text { Assu`ada }\end{array}$ & $\begin{array}{l}1 \text { Ruang } \\
(3 \times 5) \text { meter persegi })\end{array}$ \\
\hline 5. & White Board & $\begin{array}{l}1 \text { buah } \\
\text { Ukuran } 50 \times 100 \mathrm{~cm}\end{array}$ \\
\hline 6. & Kursi duduk anak & 30 buah \\
\hline 7. & Media Gambar Huruf & 1 buah \\
\hline
\end{tabular}




\begin{tabular}{|l||l||l|}
\hline No. & $\begin{array}{l}\text { Nama Sarana dan } \\
\text { Prasarana }\end{array}$ & Keterangan \\
\hline 8. & Poster-poster gambar lucu & 8 buah \\
\hline 9. & $\begin{array}{l}\text { Gambar-gambar hitungan } \\
\text { matematika }\end{array}$ & 2 buah \\
\hline
\end{tabular}

(CD.5)

\section{Pembahasan :}

Sarana dan Prasara yang ditemukan dalam RA Assu `ada sebaiknya dioptimlakan sesuai dengan standar sarana dan prasaran pengelolaan pendidikan PAUD dalam hal ini RA dalam Peraturan Pemerintah No.17 tahun 2010. Bahkan RA Assu ada dapat mengajukan bantuan ke beberapa lembaga terkait berkenaan dengan penambahan sarana dan prasara seperti di direktorat PAUD dan lain-lain.

\section{Media Pembelajaran}

Media sebagai salah satu komponen dari strategi pembelajaran yang dimiliki oleh RA Assu'ada perlu ditambah dan dikembangkan kerana masih minim jumlahnya (CD.6)

\section{Pembahasan:}

RA Assu'ada perlu menambah jumlah media dan meningkatkan kualitas edukasinya sehingga dapat meningkatkan kualitas dan mempengaruhi proses strategi pembelajaran nilainilai agama sehingga akan meningkatkan mutu atau kwalitas hasil pendidikan. Jumlah media yang dimiliki oleh RA Assu ada sebaiknya sebanding dengan banyaknya peserta didik. Pada akhirnya diharapkan anak dapat aktif dalam proses pembelajaran dengan dukungan media yang ada. Bahkan RA Asyu ada dapat mengajukan bantuan media dan sumber belajar ke direktorat PAUD dan yang lain.

\section{KBM (Kegiatan Belajar Mengajar) dalam Aplikasi Strategi Pembelajaran Nilai-nilai Agama}

Proses KBM di RA Assu’ada:

1. Waktu belajar anak senin sampai jum`at

2. Sebelum kelas ini dipakai oleh anak Raudhatul Athfal (4-6 tahun) sebelumnya dipakai belajar oleh anak usia KB(Kelompok Bermain) 3-4 tahun. Sehingga berkesan kejar-kejaran waktu.

3. Untuk anak RA masuk kelas pada pukul $09.30-12.00$ WIB.

4. Untuk hari Kamis baik anak RA dengan KB digabung. Jumlah siswa RA 53 anak. Sedangkan jumlah siswa KB 20 Jumlah siswa semua 73 anak 


\section{Pembahasan :}

RA Assu ada adalah RA yang dipercaya oleh masyarakat ditunjukkan dengan jumlah murid yang sangat banyak setiap semester. Oleh sebab itu mutu Proses Kegiatan Belajar Mengajar sebagai salah satu komponen dalam Strategi Pembelajaran Nilai-nilai Agama di Raudhatul Athfal agar ditingkatkan secara optimal. KBM yang terjadi sifatnya harus bervariatif. Bahkan perlu juga ditingkatkan ke pengembangan kreativitas anak dan inovatifnya. Dalam rangka meningkatkan mutu KBM agar lebih baik dan terarah maka guru dianjurkan untuk terus mengikuti berbagai seminar dan workshop tentang peningkatan KBM.

\section{Penilaian / Evaluasi}

Bentuk laporan mengenai perkembangan anak menggunakan data deskriptif untuk tiap semester (semester I dan semester II). Adapun untuk penilaian perkembangan anak yang sifatnya harian ataupun menggunakan simbol-simbol bintang, bulan tersenyum, dan matahari menangis. Selain itu ada laporan perkembangan anak yang lain seperti fortopolio. (CD.6)

\section{Pembahasan:}

RA Assu ada melakukan proses penilaian atau evaluasi baik hasil prestasi belajar anak maupun dalam penggunakan strategi pembelajaran nilai-nilai agama pada anak. Perlu dikembangkan dan ditingkatkan penggunaan aplikasi penilaian yang bervariasi seperti penilaian-penilaian yang lain misalnya anekdot dan perkembangan yang lain seperti setiap minggu dan setiap bulan sebagai laporan yang sistematis.

\section{H. Rekomendasi}

Diharapkan Kementrian Agama lebih memberikan perkatian lagi pada lembaga Raudhatul Athfal dengan cara:

a. Memberikan bantuan beasiswa bagi guru-guru RA untuk melanjutkan S1 PGRA/PAUD dalam rangka meningkatkan kompetensi profesi guru.

b. Memberikan bantuan sarana dan prasarana, serta media pembelajaran guna mendukung keberhasilan proses pembelajaran secara optimal, ditandai hasil belajar dan prestasi anak meningkat. 
c. Kementrian Agama diharapkan sering mengadakan seminar, workshop atau TOT secara gratis dalam meningkatkan potensi guru RA.

d. Kementrian Agama melakukan sosialisasi Kurikulum RA produk secara lebih intensif.

\section{Penutup}

RA Assu`ada belum menerapkan strategi pembelajaran nilai-nilai agama secara optimal disebabkan oleh beberapa faktor:

1. Fasilitas kelas di RA Assu ada perlu ditingkatkan, ditambah atau dikembangkan terutama yang memiliki nilai edukatif tinggi.

2. Media pembelajaran yang dimiliki oleh RA Assu`ada perlu ditingkatkan jumlahnya sehingga dapat mendukung dalam proses strategi pembelajaran nilai-nilai agama secara optimal.

3. Guru-guru yang masih memiliki kualifikasi SMA dan belum memiliki kompetesi sebagai guru RA sesuai dengan UU Guru No.14 tahun 2005 yaitu kompetensi pedagogik, professional, social, dan social perlu melanjutkan studi.

4. Metode yang digunakan dalam aplikasi strategi pembelajaran nilai-nilai agama di RA Assu ada oleh guru perlu bervariasi sehingga hasil belajarnya anak lebih optimaldan tidak membosankan.

5. Kurikulum yang digunakan perlu mengacu pada kurikulum dari Kementrian Agama yang memiliki karakteristik dan esensi keagamaannya dan dikolaborasikan dengan kurikulum 2013 PAUD.

6. Kegiatan Belajar Mengajar perlu ditingkatkan secara efektif dan efisien disebabkan jumlah anak dengan jumlah guru belum seimbang

7. Silabus dan RKH sebagai panduan dalam kegiatan pembelajaran sebaiknya selalu dibuat agar guru memiliki arah pembelajaran yang jelas dan terarah. 


\section{Daftar Pustaka}

Ann Brewer, Early Chilhood Education Preschool Through Primary Grades, ( University of Maddachusett Lowell : Pearson, 2007 ), p. 386 Arikunto Suharsimi, Prosedur Penelitian suatu Pendekatan Praktek, ( Rieneka Cipta: Jakarta, 2006), 97

Cosby S. Rogers dan Jamet K Sawyers, Play in The Lives of Children, (Washington DC: NAEYC, 1995'0, p.3

Departemen Pendidikan Nasional, Contextual Teaching and Learning (CTL), (Jakarta : Direktorat Pendidikan Dasar dan Menengah, 2003 ), 3

Departemen Pendidikan Nasional, Standar Perkembangan Dasar Pendidikan Anak Usia Dini (Jakarta : Direktorat Pembinaan TK dan SD Universitas Negeri Jakarta, 2007)

Nana Sujana, Penilaian Hasil Proses Belajar Mengajar, (Bandung: Rosda Karya, 2005)

Nurhadi, Kurikulum 2004 Pertanyaan \& Jawaban ( Jakarta: Grasindo,2004 ), 19

Pusat kurikulum, Direktorat pendidikan anak usia dini, Direktorat pembinaan TK danSD, Universitas Negeri Jakarta, Standar perkembangan dasar Pendidikan anak usia dini, (Jakarta: Departemen Pendidikan Nasional, 2007), 1

User Usman , Menjadi Guru yang Profesional, (Bandung: Rosda Karya, 1989), 29

Yuliani Nurani Sujiono dkk, Metode Perkembangan Kognitif, ( UT: Universitas Negeri Jakarta, 2005), 18, 34-35 